\title{
Acute myocardial infarction in an elderly patient treated for lung cancer
}

\section{Piotr Plecka}

Department of Medicine and Health Sciences, University of Zielona Góra

Oncology Clinic in Dębno Lubuskie

\section{ABSTRACT}

There is a growing number of elderly patients, so it is necessary to create new standards of oncologic

Correspondence: Piotr Plecka Specjalistyczna Praktyka Onkologiczna 69-100 Stubice, ul. Lisia 11 e-mail:pplecka@wp.pl

Received: 8.08.2018

Accepted:

9.10.2018

DOI: 10.24292/01.OR.0901018 Copyright $\odot$ Medical Education. All rights reserved. care for such individuals in order to provide them with the best possible treatment.

An elderly woman was treated for locally advanced small-cell lung cancer. Due to the suspicion of coronary disease, arterial hypertension and age, anti-cancer treatment with carboplatin and etoposide was recommended. When carboplatin infusion came to a stop, signs of myocardial infarction in ECG as well as elevated levels of troponin I were reported. Originally, non-invasive treatment was introduced, but several days later three DES stents were placed in coronary arteries. An attempt was made to treat the patient with cisplatin and etoposide, after which respiratory failure, tumor lysis syndrome and pancytopenia occurred. That is why chemotherapy was discontinued at the time. The patient's tumor area and brain was irradiated. 16 months later, she is still alive without signs of disease progression. New oncologic standards should be elaborated in order to ensure appropriate treatment for elderly patients.

Key words: myocardial infarction, carboplatin cardiotoxicity, elderly patients 


\section{INTRODUCTION}

The ever increasing number of elderly patients with lung cancers requires the establishment of new oncologic care standards for that age group [1, 2]. Presently, elderly patients are covered by an individual therapeutic plan that takes into account their comorbidities, general health status, and the potential side effects of the applied therapies [3]. However, despite the fact that those factors are accounted for, adverse events still occur [4]. The below described therapeutic process in an elderly patient with smallcell lung cancer is an example of complications that are difficult to predict, but also, given her long survival in spite of a non-radical treatment, a good example of how selected tumors are biologically different in elderly patients [5].

\section{CASE DESCRIPTION}

A 70-year-old patient was admitted to the Ward of Chemotherapy of the Pulmonology Hospital in Torzym for the treatment of locally advanced left lung cancer.

Her initial symptom was hemoptysis, which occurred in January 2017. For that reason, the patient was referred to the department of pulmonology for further diagnostics. On the day of admission massive hemoptysis was observed. The tests performed revealed the following findings: bronchoscopy - ostium of the left lower bronchial lobe compressed from the outside, occluded by a blood clot, with only residual lumen after lavage, rendering endoscopic passage impossible; upon coughing, the patient started bleeding from that site, which required the administration of adrenalin and thrombin, and due to the intensified coughing and dyspnea, with desaturation to $65 \%$, the examination was terminated, and oxygen was administered to the patient; chest $\mathrm{CT}$ - tumor of the left lung hilus $35 \times 34 \mathrm{~mm}$, with bronchial occlusion up to the lower lobe and its atelectasis, infiltration of the left lower lobe artery, numerous mediastinal lymph nodes (anterior, paratracheal and aortopulmonary) measuring $12 \mathrm{~mm}$ in short axis, ground-glass densities in the upper lobe and lingula of the left lung, aorta with atherosclerotic plaque, and degenerative lesions in the thoracic spine; ECG - regular sinus rhythm 100/ min, normal heart axis; in lab tests: CRP $11.7 \mathrm{mg} / \mathrm{l}$ (normal range up to $5 \mathrm{mg} / \mathrm{l}$ ), glucose $161 \mathrm{mg} / \mathrm{dl}$, hemoglobin $11.5 \mathrm{~g} / \mathrm{dl}$; in ABG: - $\mathrm{pO}_{2} 56.5 \mathrm{mmHg}$ (normal range above $83 \mathrm{mmHg}$ ), normal saturation, troponin I $12 \mathrm{ng} / \mathrm{l}$ (normal range up to $15 \mathrm{ng} / \mathrm{l}$ ). Following a thoracic surgical consultation, the patient was qualified for the EBUS examination. The following small-cell tumor pattern was revealed in the harvested material: CK(AE1/AE3)+, TTF+, CHR+/-, SYN+, CD 56+, and Ki67 antigen expression in $80 \%$ of the tumor cells. Moreover, it was established that the patient had been suf- fering from arterial hypertension, chronic obstructive pulmonary disease (COPD) group A according to GOLD, and had also been diagnosed for ischemic heart disease, but without a conclusive diagnosis offered at an outpatient clinic.

The patient was then referred for systemic treatment. Her lab tests revealed the following findings: glucose $168 \mathrm{mg} / \mathrm{dl}$, creatinine $0.87 \mathrm{mg} / \mathrm{dl}$ (normal range for females up to $1.20 \mathrm{mg} / \mathrm{dl}$ ), normal level of D-dimers, CRP 5.04 mg/l; ECG - normal reading; normal arterial blood pressure; weight $77 \mathrm{~kg}$, height $155 \mathrm{~cm}$, body surface area $1.76 \mathrm{~m}^{2}$, BMI 32.05. Due to the patient's concomitant diseases, her general health condition (WHO performance status: $1 / 2$ ) and age, she was qualified for treatment with the CE regimen dosed at: carboplatin $300 \mathrm{mg} / \mathrm{m}^{2}$ - day 1, etoposide 120 $\mathrm{mg} / \mathrm{m}^{2}$ - day $1-3$, or $550 \mathrm{mg}$ and $200 \mathrm{mg}$, respectively. On the day of the initiation of treatment, the patient suffered from drops in arterial blood pressure and anxiety. The dose of antihypertensive drugs was reduced, and a tranquilizing agent was administered, with the underlying assumption that the symptoms had been caused by the stress related to hospitalization and initiation of chemotherapy. Once the patient's condition had stabilized, the therapy started with the infusion of carboplatin. Towards the end of the infusion time, anxiety returned, alongside retrosternal discomfort, and a drop in arterial pressure to $110 / 60 \mathrm{mmHg}$. ECG test was performed, revealing no ischemic reactions, and the first measurement of the troponin I concentration was performed at that time as well, revealing normal values. However, it was decided that etoposide would not be administered to the patient. The tests were to be repeated one hour later. At that time, the level of troponin I increased to $138 \mathrm{ng} / \mathrm{l}$ (normal range up to $50 \mathrm{ng} / \mathrm{l})$, and the ECG test revealed ST depression in leads I, II, III, $a V F, V_{2}-V_{6}$. The consecutive measurements indicated a systematic increase in troponin I levels (up to $524 \mathrm{ng} / \mathrm{l}$ ), and the patient started presenting with typical symptoms of angina pectoris. Hence, the physician on duty decided that the patient should be transferred to the department of cardiology. As his request was rejected twice, the patient was instead transferred to the intensive pulmonary care unit. Standard cardiac therapy was initiated, and as a result the patient's symptoms gradually receded. Additionally, an echocardiogram was performed, revealing a slight degeneration of aortic valve leaflets, without contractility disorders, and the LVEF of 58\%. In the subsequent ECG readings, Pardee's wave was not observed. On day 7 of hospitalization, the patient was discharged from hospital.

As the patient's anginal symptoms returned, she was later hospitalized at the department of cardiology, where she was qualified for invasive diagnostics of coronary arteries. Coronary angiog- 
raphy was performed, revealing a critical stenosis of the right coronary artery, and a significant stenosis of the left anterior descending (LAD) artery. Therefore, two Resolute Onyx drug-eluting stents (DES) were placed in the right coronary artery, and 3 days later, the same type of stent was placed in the LAD. Lab tests revealed elevated levels of ALT - $110 \mathrm{U} / \mathrm{I}, \mathrm{AST}-56 \mathrm{U} / \mathrm{I}, \mathrm{BNP}$ $218 \mathrm{pg} / \mathrm{ml}$ (normal range up to $125 \mathrm{pg} / \mathrm{ml}$ ), LDL cholesterol - 109 $\mathrm{mg} / \mathrm{dl}$ (normal range up to $100 \mathrm{mg} / \mathrm{dl}$ ), blood glucose $-147 \mathrm{mg} /$ $\mathrm{dl}$, and troponin $\mathrm{T}-0.126 \mathrm{ng} / \mathrm{ml}$ (normal range up to $0.014 \mathrm{ng} /$ $\mathrm{ml}$ ). Echocardiogram revealed a compromised diastolic function of the left ventricle (in Doppler imaging of mitral inflow). The patient's antihypertensive treatment was modified, she was started on cholesterol-lowering and anticoagulant drugs (acetylsalicylic acid and clopidogrel).

Four weeks from the myocardial infarction, the patient was admitted to the department of clinical oncology at a reference center for the continuation of anti-cancer therapy. A follow-up echocardiogram revealed no contractility disturbances, and the LVEF was $60-65 \%$ at the time. It was decided that the therapy would continue based on the PE regimen, with the following doses: $50 \mathrm{mg}$ of cisplatin on days $1-3$, and $200 \mathrm{mg}$ of etoposide on days $1-3$. On day 3 of the treatment, dyspnea occurred. On the following day, respiratory insufficiency was reported, requiring intubation with assisted breathing and oxygen therapy. At the same time, laboratory signs of the tumor lysis syndrome were observed, including elevated levels of creatinine $(2.25 \mathrm{mg} / \mathrm{dl})$, uric acid ( $12 \mathrm{mg} / \mathrm{dl}$; normal range up to $7.0 \mathrm{mg} / \mathrm{dl}$ ), urea nitrogen ( $86.9 \mathrm{mg} / \mathrm{dl}$; normal range up to $22.0 \mathrm{mg} / \mathrm{dl})$, ALT (272.9 U/l), AST $(69.9 \mathrm{U} / \mathrm{l})$, phosphorus $(4.76 \mathrm{mg} / \mathrm{dl}$; normal range up to $4.50 \mathrm{mg} /$ dl). On day 4 following the chemotherapy, the patient's hemoglobin level dropped to $7.7 \mathrm{~g} / \mathrm{dl}$, and her platelet count dropped to 82 thousand. Starting from day 8 , her leukocyte levels began to drop, eventually reaching the concentration of 0.55 thou/ $\mu \mathrm{l}$, and her neutrophil level dropped to 0.05 thou/ $\mu$ l. Thanks to the administration of symptomatic treatment, gradual improvement of the patient's overall condition and hematologic parameters was accomplished. Due to the complications observed, systemic therapy was discontinued. A follow-up chest CT revealed partial regression of the lesions. The patient was then qualified for radiotherapy. Two months from the termination of chemotherapy, the patients was irradiated in the tumor area and in the area of the mediastinal lymph nodes at the dose of $46.0 \mathrm{~Gy}$ in 2 Gy fractions, with an increased dose of $60.0 \mathrm{~Gy}$ to target the tumor itself. The final treatment stage involved irradiation of the brain at the dose of $25 \mathrm{~Gy}$ in $2.5 \mathrm{~Gy}$ fractions, which was completed 7 months after the chemotherapy.
The patient has been alive for 16 months since the beginning of treatment, and the consecutive two follow-up chest CT tests confirmed tumor regression.

\section{DISCUSSION}

Treating elderly patients is challenging for oncologists. The presence of chronic diseases and the incertitude as to the patient's own reserves alongside the necessity of applying the most efficacious treatment possible make the decision-taking process extremely difficult [6].

In the above described case, carboplatin was selected instead of cisplatin due to the suspicion of coronary artery disease, arterial hypertension, the patient's overall condition and age, all of which constituted significant contraindications for cisplatin use. When calculating the dose of carboplatin, body surface area was taken into consideration (lower end of the range), with the result being similar to the value calculated based on the Calvert's formula for carboplatin dosage $[7,8]$.

Cardiac complications following the administration of carboplatin are listed as rare or very rare in the drug's Summary of Product Characteristics. One can find more information in literature on the toxicity of cisplatin, especially after a completed therapy [9]. However, Kim et al. demonstrated that the incidence of arterial thrombosis was higher in the group of lung cancer patients treated with carboplatin than in the group treated with cisplatin [10]. In the above described case, the patient presented with a full clinical and laboratory picture of myocardial infarction as a result of carboplatin administration, which is why we may assume that in her case the cytotoxic drug manifested its cardiotoxicity.

What is difficult to understand is the fact of administering a cisplatin-based chemotherapeutic regimen at a later stage, with doses calculated based on the patient's weight. Complications that occurred in the wake of the cisplatin-based chemotherapy indicate that the decision was wrong. There are no strict guidelines as to the period of time which should elapse from an episode of MI to the initiation of the next treatment cycle. It appears that the management of all three stenotic sites in coronary arteries with stents, and the lack of contractility disorders paired with a normal LVEF in the follow-up echocardiogram might have encouraged the attending physicians to decide in favor of an early continuation of systemic therapy. A separate issue to be considered is the refusal to treat the patient with $\mathrm{Ml}$ at the department of cardiology, which might have affected the quality of the cardiac treatment provided and of the delayed stent implantation. 
The choice of drug-eluting stents itself appears to have been a good solution, despite the need to administer dual antiplatelet therapy, which might have led to hemorrhagic diathesis in the case of continuation of cytotoxic therapy.

What is also worth noting is the fact that the patient received a full dose of radiation, even though the tumor was located on the left side. The currently available devices enable very accurate radiation beam targeting, which would have probably made it possible to avoid further complications.

Despite the non-radical treatment and the life-threatening complications, the patient is still alive, without signs of disease progression. Some authors have pointed out that the underlying tumor biology may be different or more indolent in elderly patients. The above described case may be an example of just that.

\section{CONCLUSIONS}

1. In the light of a lack of standards in the treatment of lung cancer in elderly patients, we feel it is necessary to establish those.

2. Until such standards are elaborated, a case-by-case approach is indispensable.

3. In order to confirm the hypothesis of different tumor biology in elderly patients, a statistical analysis is recommended, involving a sufficiently large population of patients.

\section{References}

1. Wojciechowska U, Didkowska J. Krajowy Rejestr Nowotworów, Centrum Onkologii - Instytut im. Marii Skłodowskiej-Curie [online: onkologia.org. $\mathrm{pl} /$ raporty/ accessed 17.07.2018 r.].

2. Rechel B, Grundy E, Robine JM et al. Ageing in the European Union. Lancet 2013; 381: 1312-1322.

3. Ludbrook JJ, Truong PT, MacNeil MV et al. Do age and comorbidity impact treatment allocation and outcomes in limited stage small-cell lung cancer? A community-based population analysis. Int J Radiat Oncol Biol Phys 2003; 55: 1321-1330.

4. Kowalski DM, Szmit S. Ocena ryzyka powikłań sercowo-naczyniowych u chorych na raka płuca otrzymujących leki cytotoksyczne i ukierunkowane molekularnie. In: Krzakowski M, Opolski G, Szmit S. (ed). Postępowanie w powikłaniach sercowo-naczyniowych w raku płuca. Medical Education, Warszawa 2012: 77-85.

5. Meriggi F, Zaniboni A. Non-small cell lung cancer in the elderly. Crit Rev Oncol Hematol 2006; 57: 183-190.

6. Hurria A, Togawa K, Mohile SG et al. Predicting Chemotherapy Toxicity in Older Adults With Cancer: A Prospective Multicenter Study. J Clin Oncol 2011; 29(25): 3457-3465. DOI: 10. 1200/JCO.2011.34.7625.

7. Calvert AH, Newell DR, Gumbrell LA et al. Carboplatin dosage: prospective evaluation of a simple formula based on renal function. J Clin Oncol 1989; 7: 1748.

8. Sculier JP, Botta I, Bucalau AM et al. Medical anticancer treatment of lung cancer associated with comorbidities: a review. Lung Cancer 2015; pii: S0169-5002(15)00065-3.

9. Berliner S, Rahima R, Sidi Y et al. Acute coronary events following cisplatin-based chemotherapy. Cancer Invest 1990; 8(6): 583-586.

10. Kim ES, Baran AM, Mondo EL et al. Risk of thromboembolism in cisplatin versus carboplatin-treated patients with lung cancer. PLoS ONE 2017; 12(12): e0189410 [online: https://doi.org/10.1371/journal.pone.0189410].

Conflict of interests: 